\title{
PRIORITIZING THE MOST IMPORTANT FACTORS IN THE DESIGN OF SPATIAL STRUCTURE OF SCHOOLS BASED ON LEED STANDARDS
}

\author{
Hamid Fadakari \\ Department of Architecture, Science and Research Branch, Islamic Azad University, Zahedan, Iran \\ Maziyar.Fadakar@yahoo.com \\ Alireza Bavandian \\ Department of Art, University of Neyshabur, Neyshabur, Iran \\ Bavandian@,ferdowsi.um.ac.ir
}

\begin{abstract}
In order to achieve spatial configuration of schools focusing on sustainability based on LEED certification, this paper attempted to identify criteria and indicators of this standard for measuring sustainability and then, it prioritized them using Analytic Hierarchy Process (AHP).In this paper, to explain priorities of the most important factors in design of schools based on LEED standards, main criteria for decision-making and Analytic Hierarchy Process included five items of site sustainability, efficiency of water, energy and atmosphere, materials and resources, quality of indoor air, and innovation and creativity in design with spatial fluidity and fluency in regard with planning and design guidelines set by LEED. The results showed that main five identified criteria can be listed in order of priority as efficiency of water, energy and atmosphere, materials and resources, site sustainability, innovation and creativity in design with spatial fluidity and fluency, and quality of indoor air, respectively.
\end{abstract}

Keywords: prioritization, spatial configuration design, schools, LEED standards, Analytic Hierarchy Process (AHP)

\section{INTRODUCTION}

Population growth and consequently exceeding demand for energy consumption, resource depletion of fossil fuels, increased air pollution caused by burning fossil fuels, destruction of the ozone layer, intensifying phenomenon of global warming and its side effects such as melting glaciers, floods, landslides, etc. are factors which propel modern societies to support clean, sustainable and renewable energy (Douglas and Gordon, 2010). Hence, American countries and then European countries included creation of eco-friendly environments as their administrative plans in their tremendous governmental programs in order to protect urban environment and first established this strategy at universities (Olomolaiye et al, 2007). Except activities associated with constructing multi-purposes public green spaces, no exclusive activity have been conducted yet to reduce carbon emissions in Iran (Siadat, 2013). However, given the large potential available in some Iranian cities, necessity of creating eco-friendly environments becomes obvious in those cities. In recent years, many schools and universities and other organizations have been done numerous activities in this regard but unfortunately, they could play an important role in solving environmental problems and air pollution (Tahersima et al, 2015). The community can be aware of desirability and economic and environmental value of energy, referred as harmless and quiet energy, through architecture; and teaching and learning these values may protect society from mere consumerism (Beltran et al, 2009).

The school is one of the first social environments where human enters and forms its personality. Impact of educational spaces on quality of training and behavior of students and teachers results in a close 
relationship between architecture and education (Behrouzfar, 2002).In current situation, design of schools is only concentrated on conventional and mechanical function of education and school is noticed as an educational institution. But in desirable conditions, ecological principles would be more considerable than other dimensions (Ghaffari and Hosseini, 2008). Since schools are public buildings with high energy consumption, proposing solutions for their proper designs based on targets of sustainable development may prevent from energy loss in such places and indirectly cause awareness of importance of energy optimization (Safari and Malek Mahmoodi, 2011).

Generally, due to lack of culture of using energy properly, school buildings like other ones are not designed based on principles of energy saving and environmental protection in contemporary architecture of our country(Singeri et al, 2013); especially while providing natural light and air quality can cause profound and lasting effects onqualitativeimprovement of students' acquisition -as well as learningbecause psychological security of students leads to numerous educational development (Olson and Stephen, 2003).

Given clear objectives in order to achieve self-sufficiency in energy production, recycling materials and utilization of renewable energy, green Schools (eco schools) can be generalized as a model to other parts of community such as governmental and non-governmental organizations, hospitals, etc. that will eventually have a positive effect on city clearing (Said, 2007). According to the country's rich biological resources and state protective policies on eco-friendly plans to reduce environmental pollution and optimize energy consumption, and Iran's potential for skilled labor and on the other hand, natural and ecological resource limitation, it seems that implementation of research, applied and developmental studies on spread of eco-friendly technologies and creating eco (green) schools and educational spaces and communities to address environmental and ecological issues consistent with Iran's20-year prospect is more important (Saber Davatgaran, 2013).

This study aims to achieve principles of school design in accordance with sustainability based on LEED standards as a basis for measuring building sustainability. So the items necessary for receiving this certification such as energy savings, water efficiency and energy efficiency, effectiveness of using materials, site sustainability, use of solar and renewable energies in design and improving environmental quality of schools, etc. are studied and then criteria prioritization and sub-criteria identification are done using analytical hierarchy Process (AHP).

\section{Research methodology}

A survey research method was used in this study. Initially, main arguments of planning and design of spatial configuration of schools were investigated based on LEED standards and the most significant criteria were identified. Then, simulation was carried out to prioritize the most important criteria by Analytic Hierarchy Process (AHP) and comparative analysis; so that priority of factors in school design was explained. Hence, influential variables in decision-making were obtained after selecting the sample and collecting data. Based on relationship between the variables, hypothetical model was then proposed and evaluated by AHP. After verifying proposed model according to the average made by scoring criteria, five experts -architects and psychologists-explained priorities of identified factors through paired comparison technique. Finally, the problem was analyzed to prioritize criteria after making paired comparisons of criteria and calculating rate of incompatibility.

\section{Analytic Hierarchy Process (AHP)}

AHP was first developed by Saaty. This method is based on a hierarchical structure and helps analyst to handle critical aspects of the issue within a hierarchical structure like a family tree. This method reduces complex decisions into a number of simple comparisons and ratings; and extracting results not only helps the analyst to make the best decision, but also provides a clear rationale to choose. Analytic hierarchy 
process aims to identify preferred options and also determine rank of alternatives by taking into account all decision criteria (Saaty, 2000).Analytic hierarchy process is an effective and operational approach which is able to consider unstructured and complex decisions. This method was chosen due to characteristics of the issue as well as advantages and disadvantages of other methods of decision-making. AHP typically includes following six steps (Lee et al, 2008):

1. Defining the problem non-structurally and expressing objectives and expected results clearly

2. Changing a complex problem into decision-making elements (expressing details of criteria and alternatives).

3. Using paired comparisons between decision-making elements in order to create comparison matrices

4. Utilizing special vector method to estimate relative weights of decision-making elements

5. Calculating rate of incompatibility of matrices to ensure compatibility of decision-makers' judgments

6. Integrating weighted elements to obtain final ranking of alternatives.

Priority of elements is determined in each level after creating a hierarchical structure (the element refers to each member of the hierarchy). Preferences are quantified through a 9-point scale.

Table 1. Scale of preferences between two elements for pairwise comparisons (Saaty, 2000)

\begin{tabular}{|c|c|l|}
\hline $\begin{array}{c}\text { Preference weights } \\
\text { importance level }\end{array}$ & Definition & \multicolumn{1}{c|}{ Description } \\
\hline 1 & $\begin{array}{c}\text { Equal } \\
\text { preference }\end{array}$ & $\begin{array}{l}\text { Refers to a situation where two activities provide the same } \\
\text { contributions into an objective. }\end{array}$ \\
\hline 3 & $\begin{array}{c}\text { Moderate } \\
\text { preference }\end{array}$ & $\begin{array}{l}\text { Refers to a situation where experiences and judgments tend to } \\
\text { moderately prefer one activity over other activities. }\end{array}$ \\
\hline 5 & $\begin{array}{c}\text { High } \\
\text { preference }\end{array}$ & $\begin{array}{l}\text { Refers to a situation where experiences and judgments tend } \\
\text { tohighly / particularly prefer one activity over other activities. }\end{array}$ \\
\hline 7 & $\begin{array}{c}\text { Very high } \\
\text { preference }\end{array}$ & $\begin{array}{l}\text { Refers to a situation where an activity is very highly preferred } \\
\text { over other activities. }\end{array}$ \\
\hline 9 & $\begin{array}{c}\text { Extreme } \\
\text { preference }\end{array}$ & $\begin{array}{l}\text { Refers to a situation where an activity is extremely preferred } \\
\text { over other activities. }\end{array}$ \\
\hline $2,4,6,8$ & $\begin{array}{c}\text { Transitional } \\
\text { preference }\end{array}$ & $\begin{array}{l}\text { Refers to preferences falling somewhere within the range } \\
\text { limited by above extremes. }\end{array}$ \\
\hline Inverse & \multicolumn{2}{l}{ The inverse of each case refers to inverse comparisons. } \\
\hline
\end{tabular}

Pair wise comparisons are based on the extent to which an element $\mathrm{A}$ is more important than another element B. In analytic hierarchy process (AHP), elements at each level are compared, in a pair wise manner, to the corresponding elements at a higher level; according to the pairwise comparison, they have their weights calculated (typically referred to as relative weights). Afterwards, combining the relative weights, one can end up establishing ultimate weight of each alternative (absolute weight). The ultimate weight is obtained by sum of importance factor of the criteria multiplied by the alternatives' weights. When the obtained matrix is inconsistent, weight calculation would not be an easy task to perform, requiring such methods as least squares, logarithmic least squares, eigenvector method as well as approximating approaches (Asgharpoor, 2008). In the present research, eigenvector method is followed to achieve such a purpose.

Pair wise comparisons include study of a matrix of relative ranks at each hierarchical level. Number of the matrixes depends on the number of elements at each level. Moreover, rank of the matrix at each level relates to the number of elements at the lower level. Once finished with forming all of the matrixes and performing pairwise comparisons, eigenvectors or relative weights (relative importance of the elements), 
e.g. ultimate weights, and maximum eigenvalue $\left(\lambda_{\max }\right)$ were calculated for each matrix (Expert Choice, 2000).

One of the important advantages of AHP is its ability to measure and control consistency of each matrix and decision. Acceptable range of inconsistency within each system depends on decision maker. However, generally speaking, Saaty suggests that, if incorporated inconsistency into a decision exceeds 0.1 , the decision maker is better to revise his/her judgments (Hajkowiczet al., 2000). Inconsistency index (II) is defined as follows:

$$
\text { I.I. }=\frac{\lambda_{\max }-n}{n-1}
$$

where $\lambda_{\max }$ represents maximum eigenvector of the matrix and $n$ denotes the matrix length. For each matrix, the result of II divided by the II of a random matrix (IIR) of the same dimension represents a proper measure of inconsistency referred to as inconsistency rate (IR). If the IR is smaller than or equal to 0.1 , the system consistency is recognized as acceptable, otherwise, one should revise the adjustment (Asgharpoor, 2008). It is worth noting that, IIR refers to the inconsistency index of the random matrix which can be obtained by calculating values of inconsistency index for matrixes whose elements' values are fully randomly assigned. The value of this index for a matrix of $n$ dimension is given in Table 2 .

Table 2. Inconsistency index of random matrixes (Saaty, 2000).

\begin{tabular}{|c|c|c|c|c|c|c|c|c|c|c|}
\hline$N$ & 1 & 2 & 3 & 4 & 5 & 6 & 7 & 8 & 9 & 10 \\
\hline$I I R$ & 0 & 0 & 0.58 & 0.9 & 1.12 & 1.24 & 1.32 & 1.41 & 1.45 & 1.45 \\
\hline
\end{tabular}

\section{Findings and results}

\section{Effective variables of research}

Various researches on the physical effect of the design of spatial structure of schools according to LEED standard show that, there are some factors (independently) largely contributing into the issue, such as planning and design topics according to LEED, as follows (LEED, 2011):

- Site sustainability,

- Water, energy and atmosphere consumption efficiency,

- Materials and resources,

- Interior air quality, and

- Innovation and creativity in designing with spatial fluidity and fluency.

In the present paper, the above factors are considered as the primary criteria for prioritizing the effective contributors into design of spatial structure of schools according to LEED standard, and once finished with determining their reliability coefficient based on the architects and designers' opinions, corresponding indexes to the criteria were established as presented in the following table.

Table 3. Factors and sub-factors affecting performance of open and semi-open spaces in terms of teach ability of students in elementary schools.

\begin{tabular}{|c|c|c|c|l|}
\hline No. & Criteria & $\begin{array}{l}\text { Reliability } \\
\text { coefficient }\end{array}$ & Count & \multicolumn{1}{|c|}{ Indexes } \\
\hline & & & 1 & $\begin{array}{l}\text { Prevention from pollution generation } \\
\text { through construction (M1) }\end{array}$ \\
\cline { 4 - 6 } & & 2 & Proper site selection (M2) \\
\cline { 3 - 6 } & Site sustainability (C1) & \multirow{2}{*}{0.794} & 3 & $\begin{array}{l}\text { Realizing optimum density in developed } \\
\text { areas and adjacency to the network of } \\
\text { urban services (M3) }\end{array}$ \\
\cline { 4 - 6 } & & 4 & $\begin{array}{l}\text { Restoration of damaged sites and } \\
\text { environmental pollutants (M4) }\end{array}$ \\
\cline { 3 - 5 } & & 5 & Maximization of open space and \\
\hline
\end{tabular}




\begin{tabular}{|c|c|c|c|c|}
\hline & & & & environmental access (M5) \\
\hline \multirow{6}{*}{2} & \multirow{6}{*}{$\begin{array}{l}\text { Water, energy, and } \\
\text { atmosphere consumption } \\
\text { efficiency }(\mathrm{C} 2)\end{array}$} & \multirow{6}{*}{0.899} & 1 & $\begin{array}{l}\text { Ensuring proper operation of buildings' } \\
\text { energy systems (M6) }\end{array}$ \\
\hline & & & 2 & $\begin{array}{l}\text { Optimization of minimum energy } \\
\text { consumption within building (M7) }\end{array}$ \\
\hline & & & 3 & $\begin{array}{l}\text { Prevention from ozone depletion by } \\
\text { cooling facilities (M8) }\end{array}$ \\
\hline & & & 4 & $\begin{array}{l}\text { Reduction of water consumption and } \\
\text { saving on consumption (M9) }\end{array}$ \\
\hline & & & 5 & $\begin{array}{l}\text { Wastewater recycling using creative } \\
\text { technologies (M10) }\end{array}$ \\
\hline & & & 6 & $\begin{array}{l}\text { On-site use of renewable resources and } \\
\text { green energies (M11) }\end{array}$ \\
\hline \multirow{5}{*}{3} & \multirow{5}{*}{ Materials and resources (C3) } & \multirow{5}{*}{0.834} & 1 & $\begin{array}{l}\text { Storing and collecting materials for } \\
\text { recycling format (M12) }\end{array}$ \\
\hline & & & 2 & $\begin{array}{l}\text { Reuse of the building while preserving } \\
\text { walls, floors, and non-structural elements } \\
\text { (M13) }\end{array}$ \\
\hline & & & 3 & $\begin{array}{l}\text { Management of resulting wastes from } \\
\text { construction (M14) }\end{array}$ \\
\hline & & & 4 & $\begin{array}{l}\text { Use of local and vernacular materials and } \\
\text { products of high renewal rates (M15) }\end{array}$ \\
\hline & & & 5 & $\begin{array}{l}\text { Reuse of used and recycled materials and } \\
\text { products (M16) }\end{array}$ \\
\hline \multirow{4}{*}{4} & \multirow{4}{*}{ Interior air quality $(\mathrm{C} 4)$} & \multirow{4}{*}{0.910} & 1 & $\begin{array}{l}\text { Obtaining minimum desired air quality } \\
\text { within building (M17) }\end{array}$ \\
\hline & & & 2 & Increasing air/conditioning systems (M18) \\
\hline & & & 3 & $\begin{array}{l}\text { Use of materials of low pollutant content } \\
\text { as glue and gaskets, dyes and coverage, } \\
\text { flooring and woodenwares (M19) }\end{array}$ \\
\hline & & & 4 & $\begin{array}{l}\text { Controlling of chemical and biological } \\
\text { pollutants and dangerous partiicles within } \\
\text { construction's interior space (M20) }\end{array}$ \\
\hline \multirow{4}{*}{5} & \multirow{4}{*}{$\begin{array}{l}\text { Innovation and creativity in } \\
\text { designing with spatial fluidity } \\
\text { and fluency (C5) }\end{array}$} & \multirow{4}{*}{0.832} & 1 & $\begin{array}{l}\text { Designing and audit of thermal comfort } \\
\text { systems (M21) }\end{array}$ \\
\hline & & & 2 & $\begin{array}{l}\text { Controllability of } \mathrm{A} / \mathrm{C}, \text { lighting, and } \\
\text { thermal (M22) }\end{array}$ \\
\hline & & & 3 & $\begin{array}{l}\text { Light provision and natural perspective } \\
\text { (N23) }\end{array}$ \\
\hline & & & 4 & $\begin{array}{l}\text { Balanced distribution of spaces and } \\
\text { continuation of the space fluidity with } \\
\text { designing according to LEED (M24) }\end{array}$ \\
\hline
\end{tabular}

\section{Research model expression}

According to previous discussions, the present research is indicative of a relation among five factors affecting the design of spatial structure of schools: (1) site sustainability, (2) water, energy, and atmosphere consumption efficiency, (3) materials and resources, (4) interior air quality, and (5) Innovation and creativity in designing with spatial fluidity and fluency; the factors are related to planning and designing topics according to LEED standard. Considering these criteria when designing modern 
schools of today, one can largely contribute into enhanced teachability of students. In order to determine priority of each criterion and recognized index, the formed AHP structure in Figure 1 is presented.

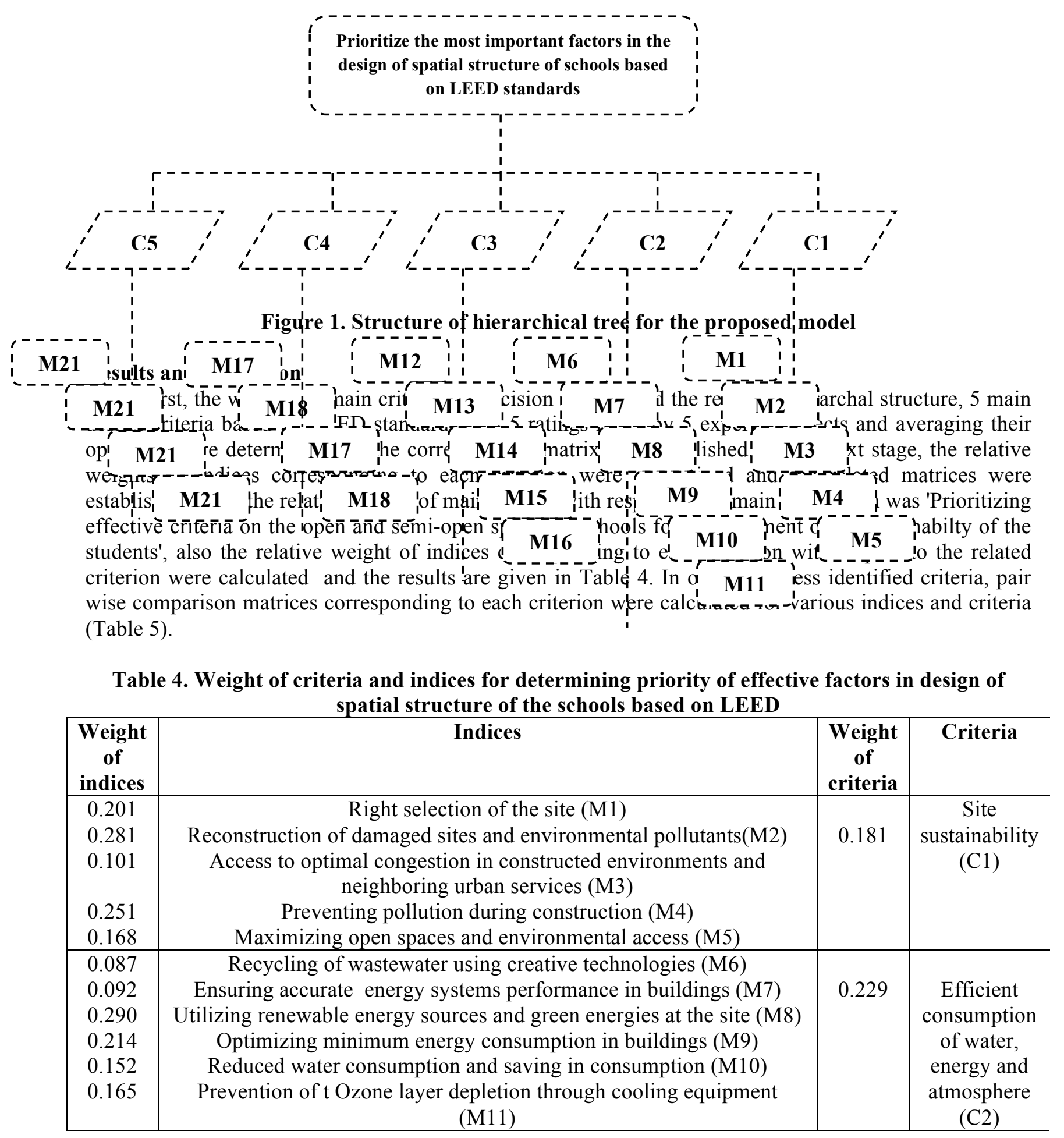




\begin{tabular}{|c|c|c|c|}
\hline $\begin{array}{l}0.261 \\
0.286 \\
0.172 \\
0.163 \\
0.122\end{array}$ & $\begin{array}{c}\text { Utilizing vernacular materials and products and with high renewability } \\
\text { rates (M12) } \\
\text { Management of wastes produced by construction activity (M13) } \\
\text { Storage and collection of recycling mold material (M14) } \\
\text { Reuse of recycled materials and products (M15) } \\
\text { Reuse of the building, and preserving walls, floors and non-structural } \\
\text { elements (M16) }\end{array}$ & 0.221 & $\begin{array}{l}\text { Materials } \\
\text { and } \\
\text { resources } \\
\text { (C3) }\end{array}$ \\
\hline $\begin{array}{l}0.169 \\
0.180 \\
0.333 \\
0.318\end{array}$ & $\begin{array}{l}\text { Access to minimum desired air quality within building (M17) } \\
\text { Use of materials with low pollution for plastering and sealing, coloring } \\
\text { and coverage, flooring and wooden products (M18) } \\
\text { Controlling chemical and biological pollutants in building's indoor } \\
\text { space (M19) } \\
\text { Increase of ventilation systems (M20) }\end{array}$ & 0.136 & $\begin{array}{c}\text { Quality of } \\
\text { indoor space } \\
\text { air (C4) }\end{array}$ \\
\hline $\begin{array}{l}0.218 \\
0.285 \\
0.273 \\
0.233\end{array}$ & $\begin{array}{l}\text { Maintaining natural light and landscape (M21) } \\
\text { Balanced distribution of space and continuation of space fluidity } \\
\text { concept in accordance with LEED (M22) } \\
\text { Design of thermal comfort system and its auditing (M23) } \\
\text { Controllability of ventilation, lighting and thermal systems (M24) }\end{array}$ & 0.163 & $\begin{array}{c}\text { Innovation } \\
\text { in design } \\
\text { with spatial } \\
\text { fluidity (C5) }\end{array}$ \\
\hline
\end{tabular}

Table 5. Weight of indices in comparison to each other with respect to the overall goal i.e. design of spatial structure of the schools based on LEED

\begin{tabular}{clllll}
\hline Sub criteria & C1 & C2 & C3 & C4 & C5 \\
\hline M1 & 0.161 & 0.216 & 0.186 & 0.154 & 0.273 \\
M2 & 0.189 & 0.219 & 0.206 & 0.184 & 0.202 \\
M3 & 0.225 & 0.259 & 0.149 & 0.171 & 0.196 \\
M4 & 0.186 & 0.207 & 0.207 & 0.193 & 0.207 \\
M5 & 0.208 & 0.240 & 0.326 & 0.129 & 0.097 \\
M6 & 0.156 & 0.242 & 0.183 & 0.206 & 0.213 \\
M7 & 0.178 & 0.226 & 0.192 & 0.199 & 0.205 \\
M8 & 0.193 & 0.215 & 0.200 & 0.193 & 0.200 \\
M9 & 0.192 & 0.226 & 0.199 & 0.196 & 0.177 \\
M10 & 0.172 & 0.275 & 0.225 & 0.167 & 0.160 \\
M11 & 0.208 & 0.234 & 0.222 & 0.156 & 0.180 \\
M12 & 0.204 & 0.214 & 0.250 & 0.159 & 0.172 \\
M13 & 0.162 & 0.197 & 0.251 & 0.169 & 0.221 \\
M14 & 0.174 & 0.229 & 0.265 & 0.149 & 0.183 \\
M15 & 0.244 & 0.260 & 0.271 & 0.142 & 0.083 \\
M16 & 0.205 & 0.205 & 0.235 & 0.150 & 0.206 \\
M17 & 0.229 & 0.223 & 0.171 & 0.1226 & 0.144 \\
M18 & 0.196 & 0.200 & 0.189 & 0.211 & 0.204 \\
M19 & 0.272 & 0.223 & 0.238 & 0.187 & 0.081 \\
M20 & 0.151 & 0.25 & 0.232 & 0.239 & 0.125 \\
M21 & 0.162 & 0.216 & 0.185 & 0.154 & 0.283 \\
M22 & 0.171 & 0.196 & 0.219 & 0.157 & 0.255 \\
M23 & 0.165 & 0.150 & 0.222 & 0.169 & 0.295 \\
M24 & 0.146 & 0.225 & 0.212 & 0.160 & 0.247 \\
\hline & & & & &
\end{tabular}


Prioritizing different criteria for spatial design of schools based on LEED with respect to 5 aforementioned main criteria is given in Fig.2. The results of pair-wise comparisons made between five main identified criteria include; criteria for efficiency in water, energy and atmosphere, material and resources, site sustainability, innovation in design with spatial fluidity and finally air quality of indoor space, which are of greater priority.

In addition, in Figs. 3-7, the results of pair-wise comparisons made between identified indices for 5 main criteria and their prioritizing are presented. The obtained results show that for the 'site sustainability' criterion, the index of 'reconstruction of damaged sites and environmental pollutants', for the 'water, energy and atmosphere efficiency' criterion the index of 'utilizing renewable energy sources and green energies at the site', For the 'materials and resources' criterion, the index of 'management of wastes due to construction activity', for the 'indoor space air quality' the index of 'controlling chemical and biological pollutants in building's indoor space' and finally for the ' 'innovation in design with spatial fluidity' criterion the index of ' Balanced distribution of space and continuation of space fluidity concept in accordance with LEED' are of higher importance in design of schools' spaces based on LEED standard.

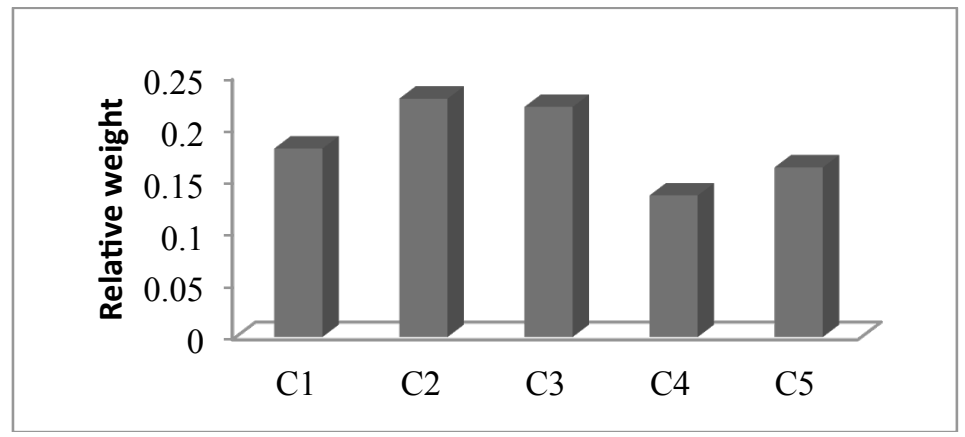

Figure 2. Priority of main criteria in design of schools based on LEED standard

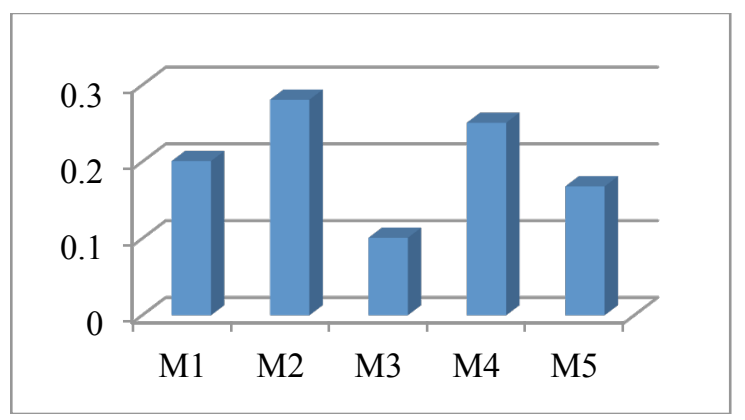

Figure 3. Priority of indices with respect to the main criterion $\mathbf{C 1}$

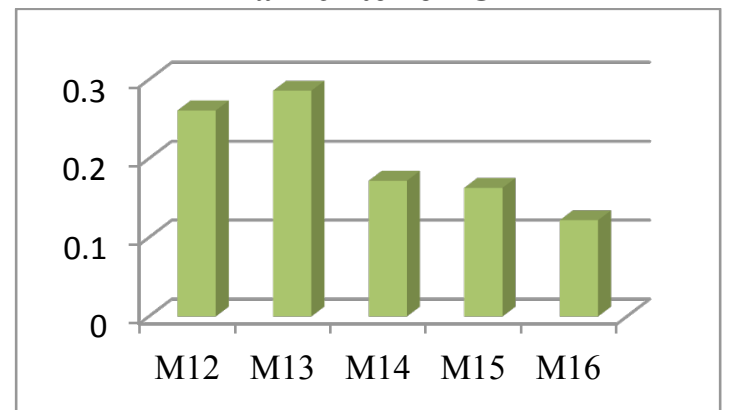

Figure 5. Priority of indices with respect to the main criterion $\mathbf{C 3}$

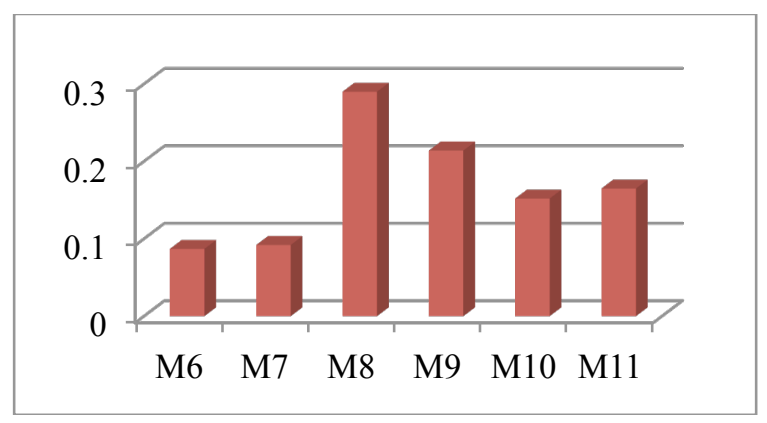

Figure 4. Priority of indices with respect to the main criterion $\mathbf{C 2}$

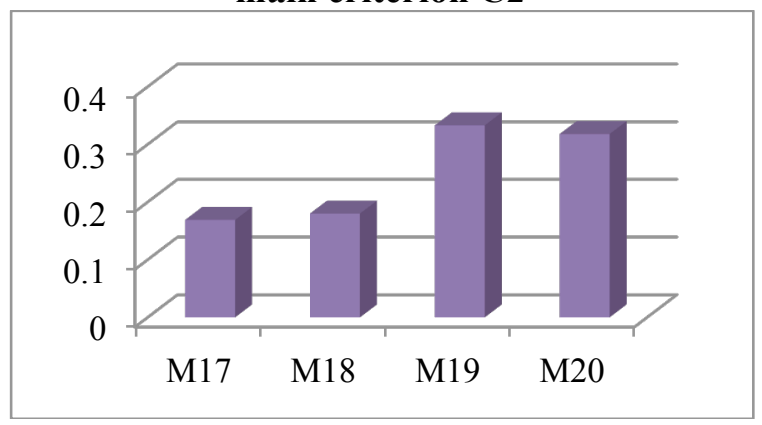

Figure 6. Priority of indices with respect to the main criterion $\mathrm{C} 4$ 


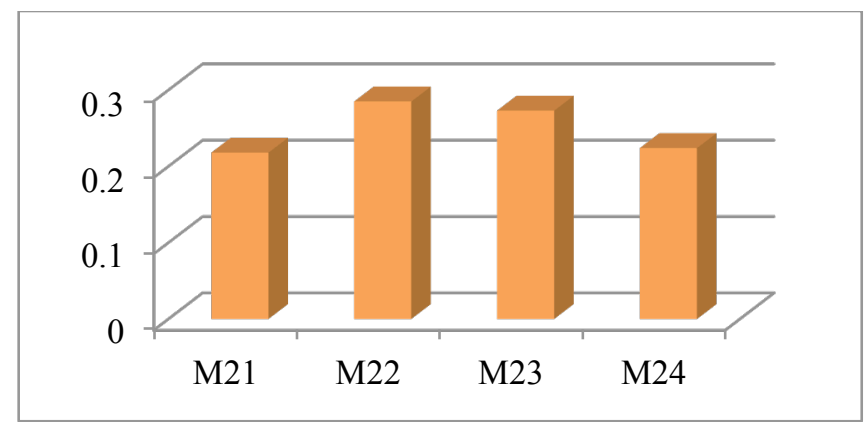

Figure 7. Priority of indices with respect to the main criterion $\mathrm{C5}$

\section{CONCLUSION}

School is among the first social environments than man enters in and his character is formed within it. The effect of educational space on education quality and behavior of the students and teachers, have produced a close relationship between architecture and education. At the present situation, the main concern in design of schools is the conventional and mechanical functionality of education and the schools are seen as similar to the educational services institutions. But with desired situation, environmental principles are of higher importance with respect to other dimensions and aspects. As schools are among public buildings with higher rates of energy consumption, presenting solutions for their right and accurate design to achieve the goals of sustainable development could largely prevent energy losses in this kind of places. For this purpose in the present article, to attain principles of spatial structure design of schools with the principality of sustainability based on LEED standard, the main criteria and indices of this standard were identified to measure the sustainability and then utilizing the Analytic Hierarchal Process (AHP) method they were prioritized.

Therefore, in this article for prioritizing the main effective factors in design of schools according to LEED standard, the main criteria of decision making and hierarchal structure of the research including 5 criteria: (1) site sustainability, (2) efficiency in water, energy and atmosphere consumption, (3) materials and resources, (4) indoor space air quality, (5) Innovation in design with spatial fluidity were established based on the topics of planning and design in LEED standard, were determined.

The results of research showed that pair-wise comparisons between the five main identified criteria , which are: 'efficiency in water, energy and atmosphere consumption', 'material and resources', 'site sustainability',' innovation in design with spatial fluidity' and finally 'indoor space air quality' are of higher priority, respectively.

In addition, prioritizing of all indices in comparison with each other and with respect to the overall goal,i.e. design of spatial structure of schools based on LEED standard showed that

for the 'site sustainability' criterion, the index of 'reconstruction of damaged sites and environmental pollutants', for the 'water, energy and atmosphere efficiency' criterion the index of 'utilizing renewable energy sources and green energies at the site', for the 'materials and resources' criterion, the index of 'management of wastes due to construction activity', for the 'indoor space air quality' the index of 'controlling chemical and biological pollutants in buildings' indoor space' and finally for the ' 'innovation in design with spatial fluidity' criterion the index of ' Balanced distribution of space and continuation of space fluidity concept in accordance with LEED' are of higher importance in design of schools' spaces based on LEED standard.

\section{REFERENCES}

Asghar Poor, Javad,'Multi-criteria decision making" Tehran University Publications, 1387 
Aragones-Beltran, P., Mendoza-Roca, J.A., Bes-Pia, A., Garcia-Melon, M., and Parra-Ruiz, E., (2009). "Application of multicriteria decision analysis to jar-test results for chemicals selection in the physical-chemical treatment of textile wastewater." J. of Hazardous Materials, 164, 288-295.

Behroozfar,Fariborz, (1381), ' Design criteria for residential open spaces in proportion to children's' psychosomaticconditions, Vol. 1, Publishing location: Tehran, Publisher: Building and Housing Research Center (BHRC).

Douglas, E., Gordon, H., 2010, Green schools as high performance learning facilities, National Institute of Building Sciences 1090 Vermont Avenue, NW, Suite 700, Washington, DC, pp. 1-14.

Expert Choice. (2000). Quick start guide \& tutorials: User's manual, PA: Expert Choice Inc., Pittsburgh.

Hajkowicz, S., Young, M., Wheeler, S., MacDonald, D., and Young, D. (2000). "Supporting decisions: Understanding natural resource management assessment techniques." CSIRO Land and Water, <http://www.clw.csiro.au/publications/consultancy/2000/sup port decisions. pdf $>$, (Apr. 5, 2004).

Saaty, T.L. (2000). Fundamentals of decision making and priority theory, 2nd Ed., PA: RWS Pub., Pittsburgh.

Siadati, Ferial Sadaat, 1392, 'Design of Iranian Garden-School as a pattern for future sustainable schools) (Design of girls' primary school)', Msc thesis, Shahrood unit Islamic Azad University, Architecture and urban planning engineering faculty, Guide professor: HamidrezaShoaei, Consultant professor: ElhamSaffarzadeh.

Singary, Maryam؛ZandiMoheb, Arezoo؛Khanloo, Nasim؛Tootoonchi, SeyyedSaeid, (1392), 'Explaining principles of sustainable schools', Vol.1, First edition, Publication location: Tabriz, Publisher: International Civil and architecture conference, Tabriz, Iran.

Safari, Zahra؛Malekmohammadi, Reza؛ (1390), 'Green school, a sustainable approach for design of educational centers', Vol. 1, First edition, Publishing location: Hamedan, Publisher:' Second national conference on sustainable architecture of SAMA educational and cultural centers of Hamedan', Hamedan, Iran.

Said I., 2007, Proceedings of International Conference Challenges and Experiences in Developing Architectural education in Asia, International Conference Challenges and Experiences in Developing Architectural education in Asia, Islamic University of Indonesia, Indonesia.

Gaffari, Hosseini, (1387), 'Design process and modeling of interdisciplinary interactions in school design' Vol. 2, First edition, Publication location: Tehran, Publisher: Second conference of Iranian school-Iranian architecture, SoorehMehr Publications.

SaberdavatGaran, Abdollah, (1392), 'LEED code, reference for environmental rating of green buildings', Vol. 1, First edition, Publication location: Mashad, First national conference on architecture and sustainable urban spaces, Mashad, Iran.

TaherSima, Sara!IraniBehbahani, Homa؛BazrAfkan, Kaveh؛ 'Explaining educational role of the open space in Iran's schools through comparative study of traditional schools up to the modern ones ( case studies: ChaharBaagh, Dar-alfonon and Alborz schools)', Islamic Architecture Research Quarterly, No. 6, Spring 1394, 3rd year.

Lee, A.H.I., Chen, W.C., and Chang, C.J. (2008). "A fuzzy AHP and BSC approach for evaluating performance of IT department in the manufacturing industry in Taiwan." Expert Systems with Applications, 34, 96-107.

LEED Committee, 2011, LEED 2009 for Schools New Construction and Major Renovations Rating System, For Public Use and Display, USGBC Member Approved, pp. 1-105.

Olomolaiye, P.O., Wahab, K.A., Price, A.D.F., 2007. Problems influencing craftsmen's productivity in Nigeria. Build. Environ. 22 (4), 317- 323.

Olson L., Stephen., 2003, The Impact of Sustainable Buildings On Educational Achievements in K12 Schools, Leonardo Academy Cleaner and Greener Program Report, November 2003. 